\title{
IDENTIFIKASI KETERDAPATAN UNSUR LOGAM TANAH JARANG DALAM ABU BATUBARA PUSAT LISTRIK TENAGA UAP OMBILIN, SUMATERA BARAT
}

\author{
Identification of Occurrence of Rare Earth Metals in Coal Ash from \\ Ombilin Electric Power Generation Plant, West Sumatera
}

\author{
SUGANAL, DATIN F. UMAR dan HASUDUNGAN E. MAMBY \\ Puslitbang Teknologi Mineral dan Batubara \\ Jalan Jenderal Sudirman 623 Bandung 40211 \\ Telp. (022) 6030483, Fax. (022) 6003373 \\ e-mail: suganal@tekmira.esdm.go.id
}

\begin{abstract}
ABSTRAK
Logam Tanah Jarang (LTJ) merupakan sumber material penting dari abad ke-21, banyak digunakan sebagai penunjang kehidupan modern seperti mobil listrik, perangkat identifikasi kesehatan (MRI, X-ray, Scanner, contrast agent, dII), LCD, hard drive komputer, pembangkit listrik tenaga angin, teknologi hijau, perangkat night vision, sistem radar dan peralatan militer. Unsur LTJ antara lain terdapat pada abu hasil pembakaran batubara dari Pembangkit Listrik Tenaga Uap (PLTU). Potensi produksi abu batubara dari PLTU di Indonesia mencapai 10 juta ton per tahun dan merupakan potensi sumber unsur LTJ yang bernilai tinggi. Penelitian ini bertujuan untuk mengidentifikasi keterdapatan unsur LTJ dalam abu batubara dari PLTU Ombilin dan proses peningkatan kadarnya. Identifikasi dilakukan dengan analisis percontoh abu batubara menggunakan XRD, XRF, ICP dan SEM. Hasil analisis menunjukkan abu batubara PLTU Ombilin mengandung Cerium, Neodimium, Lantanum, Ittrium dan Samarium meskipun kadar unsur tersebut relatif rendah, yaitu kurang dari 100 ppm. Upaya peningkatan kadar melalui benefisiasi abu terbang telah dapat meningkatan kandungan unsur Sm dari 2 ppm menjadi 9,3267 ppm pada middling, dan pada ampas meningkat dari 2 ppm menjadi 3,9429 ppm. Kandungan unsur LTJ pada abu terbang lebih tinggi dibandingkan pada abu dasar, maka upaya ekstraksi akan lebih ekonomis dilakukan terhadap abu terbang dan seyogyanya disetarakan sebagai bahan baku atau sumber senyawa LTJ. Pemanfaatan abu terbang sebaiknya didahului oleh ekstraksi unsur-unsur LTJnya, selanjutnya digunakan sebagai bahan bangunan maupun peruntukkan lain seperti yang telah berlangsung saat ini.
\end{abstract}

Kata kunci : abu batubara, abu terbang, LTJ, PLTU

\begin{abstract}
The rare earth metals as the sources of important materials from the $21^{\text {st }}$ century, are widely used as supporting materials for modern life such as electric cars, health identification devices (MRI, X-ray, Scanner, contrast agent, etc.), LCD, computer hard drives, wind-generated power plants, green technology, night vision devices, radar systems and military equipment. Rare earth metal elements also can be found in ash produced by Coal Fired Steam Power Generation Plant. The production of coal ash from the power plant in Indonesia is approximately 10 million tons per year which could be a potential source of rare earth metal elements. The aim of this study is to identify the occurrence of rare earth metal elements in coal ash from Ombilin power plant, also process to increase their concentrations. The identification was conducted by analyzing the coal ash samples using XRD, XRF, ICP and SEM. All of those coal ash contain Cerium, Neodymium, Lanthanum, Samarium and Ittrium which each metal is less than 100 ppm. Beneficiation of fly ash has been able to increase
\end{abstract}


Sm content from 2 ppm to 9.3267 ppm in middling and in tailing increased from 2 ppm to 3.9429 ppm. The content of rare earth metal elements in fly ash is higher compared to the bottom ash. The fly ash extracting process has a promising economical aspect and it should be considered as raw materials or sources of rare earth metal compounds. The utilization of fly ash should be started with the extraction of the rare earth elements first before used as building materials and other purposes at the present time.

Keywords: coal ash, fly ash, rare earth elements, power plant

\section{PENDAHULUAN}

Logam Tanah Jarang (lazim disebut LTJ) terdiri dari 17 unsur dengan rincian 15 unsur dalam kelompok lantanida dan 2 unsur lainnya yaitu Skandium dan Ittrium. Unsur LTJ meliputi La, Ce, Pr, Nd, Pm, Sm, Eu, Gd, Tb, Dy, Ho, Er, $\mathrm{Tm}, \mathrm{Yb}, \mathrm{Lu}, \mathrm{Y}$ dan Sc. Keterdapatan LTJ di alam ditemukan dalam bentuk senyawa komplek fosfat dan karbonat, umumnya berupa mineral ikutan pada mineral utama tembaga, emas, perak, timah dan lainnya (Atmawinata $d k k ., 2014)$. Tampilan fisik dari LTJ dalam bentuk oksida dapat dilihat pada Gambar 1.

Unsur LTJ dikenal sebagai sumber material penting abad ke-21, merupakan material penentu untuk mobil hibrid, perangkat identifikasi kesehatan (MRI, X-Ray, Scanner, contras agent, dII), $L C D$, hard drive komputer, fasilitas pembangkit listrik tenaga angin, teknologi hijau, peralatan dengan akurasi tinggi, perangkat night vision, sistem radar dan peralatan militer, (Zepf $d k k ., 2014$; Jegal, Thenepalli dan Ahn, 2015).

Di samping ditemukan dalam bentuk mineral ikutan di alam, unsur LTJ sering terdapat pada bahan berupa produk samping atau buangan suatu proses pengolahan dan pemurnian mineral atau sisa pembakaran. Abu batubara dan red mud dari bauksit merupakan material yang mengandung unsur LTJ. Unsur-unsur LTJ yang terkandung dalam red mud umumnya Ittrium dan Neobium, namun konsentrasinya relatif rendah, berkisar 2-12 ppm. Meski demikian, keberadaan unsur-unsur tersebut cukup berarti mengingat potensi red mud pada proses pengolahan dan pemurnian bijih bauksit sangat berlimpah (Atmawinata $d k k$., 2014). Pada abu batubara, di antaranya dalam bentuk abu terbang (fly ash) bisa mengandung konsentrasi LTJ yang relatif tinggi. Percontoh abu terbang dari salah satu Pembangkit Listrik Tenaga Uap (PLTU) di Jepang, mengandung $420 \mathrm{mg} / \mathrm{kg}$ yang setara dengan LTJ pada monasit atau basnasit $\left(\mathrm{CeFCO}_{3}\right)$ (Kashiwakura $d k k ., 2013)$. Salah satu analisis rinci unsur LTJ dalam abu batubara dari pembangkit listrik Kentucky, Amerika Serikat mempunyai kadar unsur LTJ berkisar 1.213,6-1.667,6 mg/kg total unsur tanah jarang (TREE) yang terkandung dalam abu terbang dan $1.202,5 \mathrm{mg} / \mathrm{kg}$ TREE terkandung dalam abu dasar (bottom ash). Abu batubara dalam bentuk abu dasar dan abu terbang dapat dipandang sebagai sumber unsur strategis menuju teknologi maju. Dengan demikian, potensi memanfaatkan produk pembakaran batu bara sebagai sumber untuk unsur strategis menjadi sangat jelas (Mayfield dan Lewis, 2013).

Saat ini sekitar 40\% kebutuhan listrik di seluruh dunia dipasok dari PLTU batubara, khusus di Polandia pemanfaatan batubara untuk pembangkit listrik bahkan mencapai 90 $\%$. Perkiraan instalasi pembangkit listrik dunia pada dua dasawarsa ke depan adalah sama dengan jumlah pemasangan pembangkit listrik selama abad ke 20. Pada dasawarsa saat ini telah banyak diupayakan pemenuhan energi dari energi baru terbarukan, namun demikian, peranan energi dari batubara masih sangat dominan. Oleh karena itu semua yang berkaitan dengan produk pembakaran batubara menjadi perhatian utama termasuk penanganan hasil samping pembakaran batubara dan pengaruhnya terhadap kesehatan manusia dan lingkungan secara keseluruhan (Juda-Rezler dan Kowalczyk, 2013). 


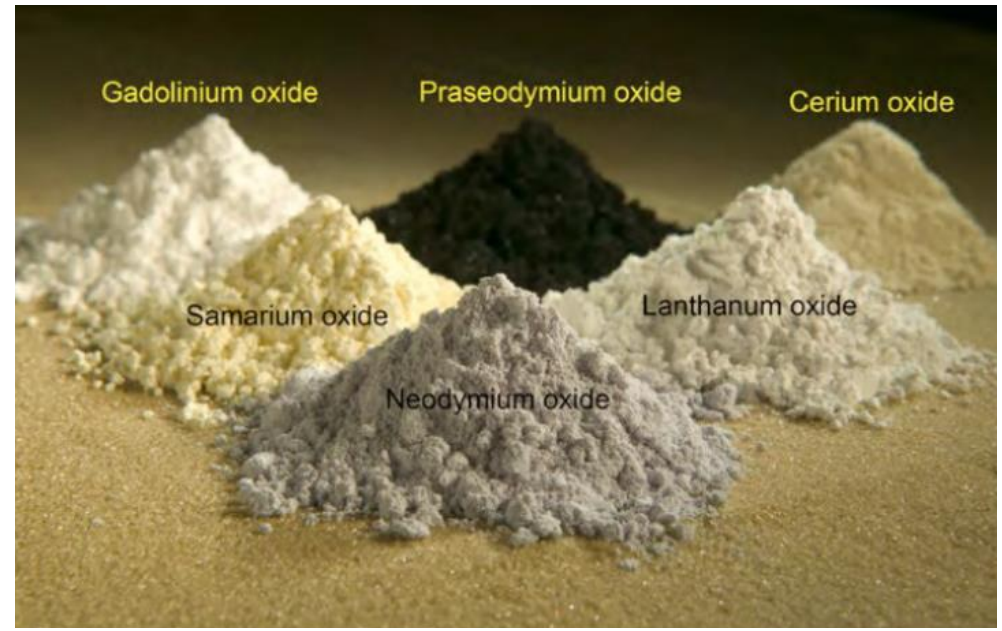

Sumber : Atmawinata dkk. (2014)

Gambar 1. Tampilan fisik oksida LTJ

Di Indonesia, pemanfaatan batubara sebagai sumber energi telah meningkat pada tahuntahun belakangan ini. Saat ini penggunaan batubara terbesar di dalam negeri adalah sebagai bahan bakar pada PLTU. Dengan meningkatnya taraf hidup masyarakat, maka keperluan akan listrik juga akan meningkat. Hal ini terlihat dengan bertambahnya pembangunan unit-unit baru pembangkit listrik yang menggunakan batubara, termasuk program 35.000 MW.

Batubara adalah batuan sedimen, terutama terdiri dari bahan organik bersama dengan sejumlah fragmen batuan anorganik dan bahan mineral, misalnya tanah liat, shale, kuarsa dan kalsit (Juda-Rezler dan Kowalczyk, 2013).

Pemanfaatan batubara pada PLTU berfungsi sebagai bahan bakar untuk boiler. Boiler akan menghasilkan uap yang digunakan sebagai penggerak turbin untuk membangkitkan listrik. Pada pembakaran batubara tersebut akan dikeluarkan sisa pembakaran berupa abu batubara dalam bentuk abu terbang (fly ash), abu dasar (dry bottom ash), boiler slag, economizer ash dan gipsum. Bagan alir pembentukan abu batubara pada PLTU terlihat pada Gambar 2.
Abu terbang adalah material limbah padatan halus terdispersi dalam gas buang PLTU, yang dipisahkan dari cairan dan gas dengan Electrostatic Precipitator sebelum dikeluarkan melewati cerobong. Komposisi terbesar (lebih dari $90 \%$ ) yang terkandung dalam abu terbang adalah silika $\left(\mathrm{SiO}_{2}\right)$, alumina $\left(\mathrm{Al}_{2} \mathrm{O}_{3}\right)$, oksida kalsium ( $\mathrm{CaO})$, dan oksida besi $\left(\mathrm{Fe}_{2} \mathrm{O}_{3}\right)$ sedangkan elemen mayor dan minor lainnya yang meliputi unsur sulfur, natrium, potasium, magnesium, titanium berkisar $8 \%$, serta jumlah komponen trace elemen (unsur kelumit) kurang dari 1\%. Trace element yang berasal dari pemanfaatan batubara pada PLTU menjadi perhatian utama dari sudut pandang kesehatan manusia meliputi $\mathrm{As}, \mathrm{Cd}, \mathrm{Cr}, \mathrm{Hg}$, Mn, Ni dan Pb (Haryadi, 2006; Juda-Rezler dan Kowalczyk, 2013). Abu dasar merupakan kumpulan butiran abu kering berasal dari sisa pembakaran batubara yang terdapat pada dry bottom furnace dengan ukuran butir sekitar 19 - $75 \mu \mathrm{m}$. Beberapa butirannya dapat dengan mudah dihancurkan dengan jari, butiran lainnya keras sulit untuk dihancurkan dan membutuhkan peralatan untuk memecahkannya. Kandungan kimia utamanya berupa senyawa silika oksida, besi oksida dan aluminium oksida. Abu dasar banyak digunakan pada produk beton dan aplikasi teknik sipil lainnya. 


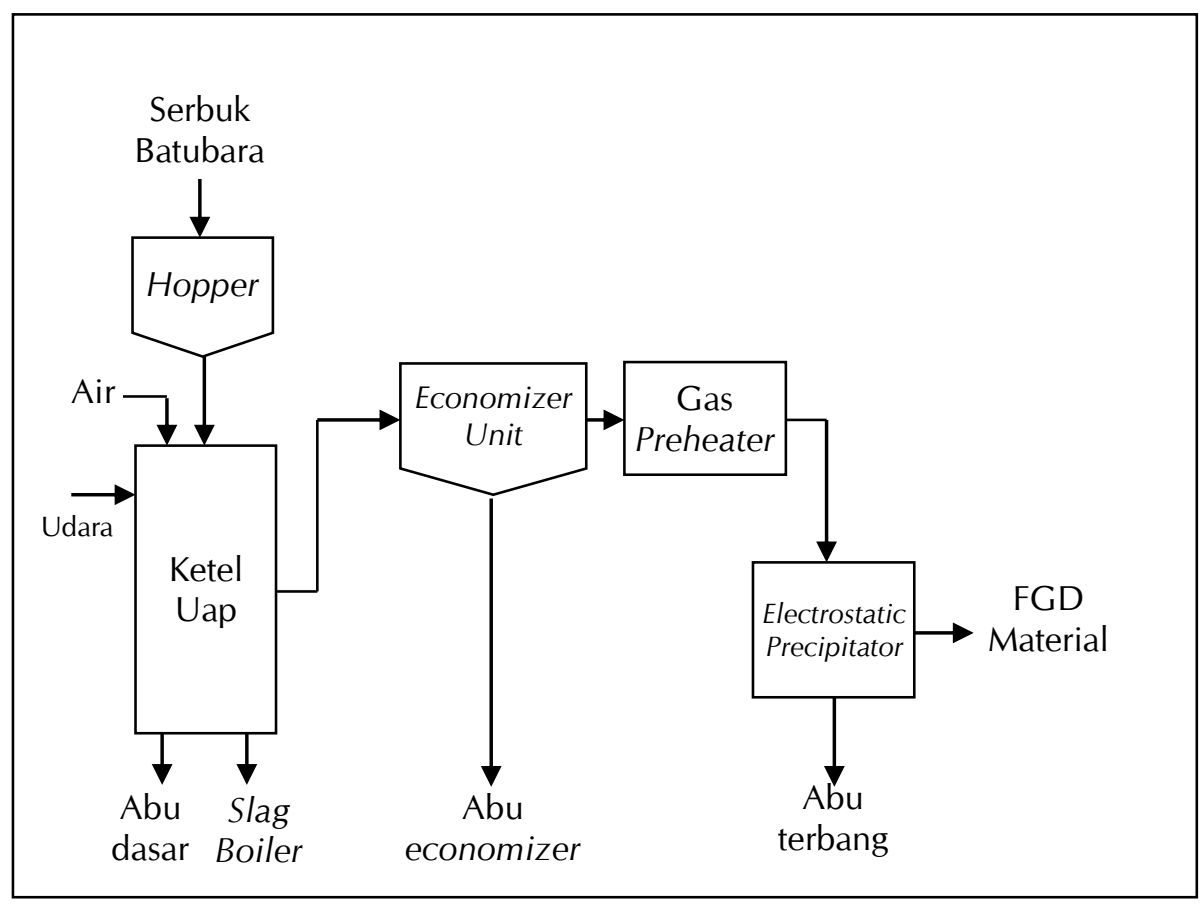

Sumber : Haryadi (2006)

Gambar 2. Bagan alir pembentukan abu batubara pada PLTU

Komposisi kimia secara umum pada abu terbang dari PLTU berdasarkan peringkat batubara yang digunakan sebagai bahan bakar terlihat pada Tabel 1. Sementara itu, dalam abu terbang terkandung pula sejumlah senyawa dalam konsentrasi relatif sangat kecil, lazim disebut unsur-unsur kelumit (trace elements). Konsentrasi unsur kelumit sangat kecil, kurang dari $1 \%$, namun di antaranya terdapat unsur-unsur logam tanah jarang. Beberapa studi pembakaran batubara berkesimpulan bahwa abu dasar dan abu terbang mengandung elemen-elemen $\mathrm{Ba}, \mathrm{Ce}$, $\mathrm{Co}, \mathrm{Cs}, \mathrm{Cu}, \mathrm{Dy}, \mathrm{Ga}, \mathrm{Ge}, \mathrm{La}, \mathrm{Lu}, \mathrm{Mn}, \mathrm{Ni}, \mathrm{Rb}$, $\mathrm{Sr}, \mathrm{Tb}, \mathrm{Th}, \mathrm{Y}, \mathrm{Yb}, \mathrm{Zn}, \mathrm{Zr}, \mathrm{As}, \mathrm{B}, \mathrm{Cd}, \mathrm{Cr}, \mathrm{Li}$, $\mathrm{Mo}, \mathrm{Pb}, \mathrm{Sn}, \mathrm{Sb}, \mathrm{Ta}, \mathrm{Tl}, \mathrm{U}, \mathrm{V}$, dan $\mathrm{W}$ tergabung dalam limbah padat, sedangkan $\mathrm{Hg}$, dan $\mathrm{Se}$ keluar ke atmosfer (International Energy Agency, 2012). Juda-Rezler dan Kowalczyk (2013) melaporkan kandungan unsur kelumit dari PLTU di Michowise dan PLTU Lagisza seperti tertera pada Tabel 2 .

Pada hakekatnya batubara mengandung cukup banyak unsur kelumit (trace element), termasuk unsur LTJ. Unsur-unsur tersebut tertambat pada abu dasar dan abu terbang dari pembakaran batubara pada pembangkit listrik. Pembakaran batubara dapat disamakan dengan proses pengkayaan (enrichment) dari beberapa unsur logam dalam abu sehingga abu batubara dapat dianggap sebagai bijih kelas rendah untuk logam, termasuk LTJ. Kandungan oksida tanah jarang dalam abu batubara sering mencapai orde persen (\%) seperti yang teridentifikasi pada abu batubara yang berasal dari Timur Jauh Rusia, jumlahnya lebih dari 1\% (Joshi, 2013). Mengingat kenyataan bahwa sejumlah besar batubara masih dibakar di seluruh dunia, di samping berdampak negatif terhadap lingkungan dan iklim, maka abu batubara dapat juga dipandang sebagai sumber penting LTJ (Binnemans $\left.d k k_{.}, 2015\right)$. Hasil pemeriksaan kadar LTJ pada batubara dan abu batubara di Amerika Serikat, Eropa, China, Meksiko, Spanyol dan Rusia telah dilaporan oleh Ahn, Thriveni dan Jegal (2015)seperti tercantum pada Tabel 3. 
Tabel 1. Komposisi kimia rata-rata dari abu terbang

\begin{tabular}{|c|c|c|c|c|}
\hline \multirow{2}{*}{ No. } & \multirow{2}{*}{ Komponen } & \multicolumn{3}{|c|}{ Komposisi, \% berat } \\
\hline & & Bituminous & Subbituminous & Lignit \\
\hline 1 & $\mathrm{SiO}_{2}$ & $20-60$ & $40-60$ & $15-45$ \\
\hline 2 & $\mathrm{Al}_{2} \mathrm{O}_{3}$ & $5-35$ & $20-30$ & $10-25$ \\
\hline 3 & $\mathrm{Fe}_{2} \mathrm{O}_{3}$ & $10-40$ & $4-10$ & $4-15$ \\
\hline 4 & $\mathrm{CaO}$ & $1-12$ & $5-30$ & $15-40$ \\
\hline 5 & $\mathrm{MgO}$ & $0-5$ & $1-6$ & $3-10$ \\
\hline 6 & $\mathrm{SO}_{3}$ & $0-4$ & $0-2$ & $0-10$ \\
\hline 7 & $\mathrm{Na}_{2} \mathrm{O}$ & $0-4$ & $0-2$ & $0-6$ \\
\hline 8 & $\mathrm{~K}_{2} \mathrm{O}$ & $0-3$ & $0-4$ & $0-4$ \\
\hline 9 & LOI & $0-15$ & $0-3$ & $0-5$ \\
\hline
\end{tabular}

Tabel 2. Kandungan trace element pada batubara dan abu batubara pada PLTU di Michowise dan PLTU Lagisza

\begin{tabular}{|c|c|c|c|c|c|c|c|c|c|}
\hline \multirow[b]{3}{*}{ No } & \multirow[b]{3}{*}{$\begin{array}{c}\text { Trace } \\
\text { Elemen }\end{array}$} & \multicolumn{8}{|c|}{ Kandungan, ppm } \\
\hline & & \multicolumn{4}{|c|}{ Michowise Power plant } & \multicolumn{4}{|c|}{ Lagisza Power plant } \\
\hline & & $\begin{array}{l}\text { Batu } \\
\text { bara }\end{array}$ & $\begin{array}{l}\text { Abu } \\
\text { dasar }\end{array}$ & $\begin{array}{c}\text { Abu } \\
\text { terbang } \\
\text { sebelum } \\
\text { ESP }\end{array}$ & $\begin{array}{c}\text { Abu } \\
\text { terbang } \\
\text { setelah } \\
\text { ESP }\end{array}$ & $\begin{array}{l}\text { Batu } \\
\text { bara }\end{array}$ & $\begin{array}{l}\text { Abu } \\
\text { dasar }\end{array}$ & $\begin{array}{c}\text { Abu } \\
\text { terbang } \\
\text { sebelum } \\
\text { ESP }\end{array}$ & $\begin{array}{c}\text { Abu } \\
\text { terbang } \\
\text { setelah } \\
\text { ESP }\end{array}$ \\
\hline 1 & As & 40,10 & 56,00 & 206,10 & 498,00 & 67,60 & 82,10 & 259,50 & 548,20 \\
\hline 2 & $\mathrm{Hg}$ & 0,09 & 0,09 & 0,02 & 0,00 & 0,08 & 0,09 & 0,01 & 0,00 \\
\hline 3 & $\mathrm{~Pb}$ & 14,30 & 20,90 & 56,60 & 280,00 & 17,60 & 30,80 & 67,50 & 380,00 \\
\hline 4 & $\mathrm{Zn}$ & 38,40 & 74,00 & 201,00 & 470,00 & 65,00 & 99,00 & 248,00 & 520,00 \\
\hline
\end{tabular}

Sumber : Juda-Rezler dan Kowalczyk (2013)

Tabel 3. Komposisi LTJ pada batubara dan abu batubara di Amerika Serikat, Eropa, China, Meksiko, Spanyol dan Rusia

\begin{tabular}{clcc}
\hline \multirow{2}{*}{ No. } & \multirow{2}{*}{ Unsur LTJ } & \multicolumn{2}{c}{ Kadar, $\mathrm{mg} / \mathrm{kg}$} \\
\cline { 3 - 4 } & & Batubara & Abu Batubara \\
\hline 1 & $\mathrm{Ce}$ & 20,9 & 468 \\
2 & $\mathrm{Dy}$ & 2,09 & 61,54 \\
3 & $\mathrm{Eu}$ & 0,28 & 7,64 \\
4 & $\mathrm{La}$ & 9,09 & 259,85 \\
5 & $\mathrm{Nd}$ & 8,48 & 236,02 \\
6 & $\mathrm{Pr}$ & 4,81 & 59,02 \\
7 & $\mathrm{~Tb}$ & 0,54 & 10,29 \\
8 & $\mathrm{Y}$ & 8,18 & 408,34 \\
9 & $\mathrm{Ga}$ & 5,24 & terbatas \\
10 & $\mathrm{Ge}$ & 4,23 & $<10-1841$ \\
11 & Te & 1,82 & terbatas \\
\hline
\end{tabular}

Sumber : Thriveni, Jegal dan Ahn (2015)

Abu terbang dari suatu PLTU berbahan bakar batubara berkisar $74 \%$ dari total abu batubara (Vulcan, 2014). Material abu terbang tersebut telah dapat digunakan secara luas antara lain pada pembuatan beton, bahan baku semen, material pengisi bekas tambang, penetral air asam tambang, bahan konstruksi jalan raya, adsorber (digunakan dalam zeolit sintetik) termasuk juga sebagai media tanaman (Terzić, Pavlović dan Miličić, 2013; Ahnl, Thriveni dan Jegal, 2015). Abu batubara dari PLTU Sangata, Kalimantan Timur terdiri dari kuarsa, mulit, aragonit, magnetit, hematit dan spinel dimanfaatkan sebagai penambah material batuan untuk pengisian kembali area penambangan. Penambahan abu sejumlah $18 \%$ dari komposisi material pengisi menunjukkan tidak adanya pengaruh kenaikan kandungan unsur kelumit logam pada aliran air dari timbunan material tersebut (Kusuma $d k k$., 2012). Sementara itu, hasil ujicoba pemanfaatan abu terbang dari pabrik tekstil di wilayah Bandung Raya untuk media tanaman tomat dengan komposisi $50 \%$ abu terbang dan $50 \%$ tanah Lembang dan ditambahkan $20 \%$ pupuk kompos menunjukkan percepatan pertumbuhan yang melebihi kontrol pada tanaman tomat dan tidak terjadi toksifikasi pada tanaman tersebut (Wardhani, Sutisna dan Dewi, 2012). Meskipun beberapa negara cukup waspada terhadap dampak negatif dari pemanfaatan abu terbang batubara, namun beberapa kegiatan penelitian menunjukkan bahwa sebagai material 
konstruksi, abu terbang aman dari pelepasan unsur-unsur logam berat yang bersifat toksik (Terzić, Pavlović dan Miličić, 2013). Bahkan pada Februari 2014, Kantor EPA (Environmental Protection Agency) memutuskan bahwa abu terbang dan gipsum dari Flue Gas Desulphurization digunakan bersama komponen beton dan papan dinding dinyatakan tidak berbahaya serta bukan sebagai bahan berbahaya (Hower, Thomas dan Hopps, 2014; Tolhurst, 2015).

Indonesia berpotensi menghasilkan abu batubara dari buangan pembakaran batubara pada PLTU berbahan bakar batubara. Informasi dari PT PLN (Persero), kebutuhan batubara untuk mengoperasikan seluruh pembangkit listrik di Indonesia mencapai 82 juta ton per tahun, bahkan meningkat menjadi 100 juta ton per tahun saat program 35.000 Mega Watt terealisasi. Hal tersebut berarti potensi jumlah abu batubara yang akan terjadi dari operasi pembangkit listrik mencapai 7,5 hingga 10 juta ton per tahun, mengingat rata rata kadar abu batubara Indonesia berkisar 7,5 - 10\%. Dengan demikian diperlukan upaya mengekstrak unsurunsur LTJ dalam abu batubara demi mendapatkan nilai tambah lanjutan dari pembakaran batubara pada PLTU berbahan bakar batubara.

Tujuan penelitian adalah mengidentifikasi keterdapatan unsur LTJ dalam abu batubara dari PLTU Ombilin dan proses peningkatan kadarnya sebagai upaya pemanfaatan batubara secara total tanpa menyisakan buangan.

\section{METODE}

Percontoh abu batubara diambil langsung dari PLTU Ombilin. Percontoh tersebut dilakukan preparasi untuk dianalisis di Laboratorium Pengujian Batubara dan Laboratorium Pengujian Mineral pada Pusat Penelitian dan Pengembangan Teknologi Mineral dan Batubara. Kegiatan analisis menggunakan $X-R D$ ( X-Ray Diffraction), XRF, Scanning Electron Microscope (SEM) dan Inductively Coupled Plasma (ICP). Selanjutnya abu terbang dikonsentrasikan berdasarkan perbedaan densitas menggunakan meja goyang. Perbedaan densitas dipilih karena perbedaan mineral yang dipisahkan relatif tinggi. Mineral silikat khususnya kuarsa $\left(\mathrm{SiO}_{2}\right)$ memiliki densitas $2,7 \mathrm{~g} / \mathrm{cm}^{3}$, magnetit memiliki densitas $5,15 \mathrm{~g} / \mathrm{cm}^{3}$, alumina silikat $\left(\mathrm{Al}_{2} \mathrm{O}_{3} . \mathrm{SiO}_{2}\right)$ densitasnya sebesar $3,69 \mathrm{~g} / \mathrm{cm}^{3}$ sedangkan abu batubara sendiri memiliki densitas $2,23 \mathrm{~g} / \mathrm{cm}^{3}$. Diharapkan mineral pengotor akan masuk ke ampas sedangkan minerat berat masuk ke konsentrat. Masing-masing hasil konsentrasi yang berupa konsentrat, middling dan ampas dianalisis menggunakan Scanning Electron Microscope (SEM).

Indentifikasi unsur LTJ pada abu terbang di PLTU Polandia juga menggunakan analisis dengan XRD, ICP dan SEM (Franus, WiatrosMotyka dan Wdowin, 2015).

Bagan alir penelitian terlihat pada Gambar 3.

\section{HASIL DAN PEMBAHASAN}

\section{Karakterisasi Abu Batubara dari PLTU Ombilin}

Hasil analisis XRF terhadap abu batubara yang berupa abu terbang dan abu dasar dari PLTU Ombilin dapat dilihat pada Tabel 4.

$\mathrm{Fe}_{2} \mathrm{O}_{3}, \mathrm{~K}_{2} \mathrm{O}$ dan $\mathrm{CaO}$. Unsur runutan (kadar $<1 \%$ ) yang bernilai ekonomi tinggi pada percontoh abu batubara dari PLTU Ombilin ini adalah; $\mathrm{Cr}, \mathrm{Cu}, \mathrm{Ni}, \mathrm{Rb}, \mathrm{Sr}, \mathrm{Pb}, \mathrm{Y}, \mathrm{Zn}$ dan $\mathrm{Zr}$. Beberapa hasil identifikasi seperti abu batubara dari PLTU di Indonesia maupun luar negeri antara lain Serbia dan Jepang dengan memanfaatkan XRF untuk analisis menunjukkan komposisi yang relatif sama besar (Kashiwakura dkk., 2013; Terzić, Pavlović dan Miličić, 2013). Pada analisis dengan XRF ini, unsur-unsur LTJ belum terlihat kecuali Ittrium $(\mathrm{Y})$. Kadar unsur LTJ dalam abu batubara kecil ( $<100$ ppm). Untuk mempertajam analisis unsur LTJ dalam abu batubara perlu dilakukan analisis menggunakan ICP karena limit deteksinya mencapai ppb (Smith, Campbell dan Nielson, 2006). Hasil analisis ICP percontoh abu batubara PLTU Ombilin dapat dilihat pada Tabel 5. 


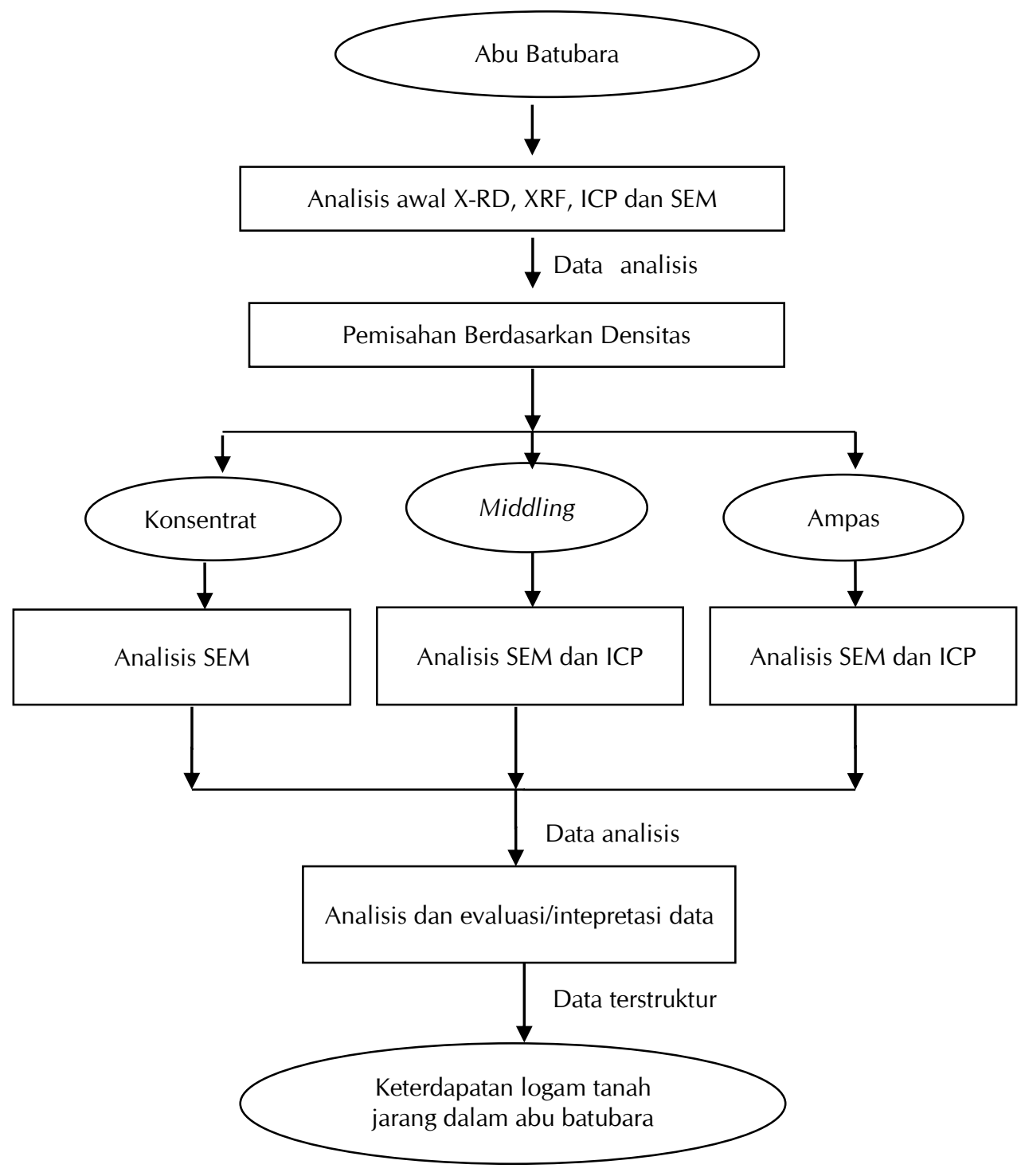

Gambar 3. Bagan alir kegiatan penelitian

Tabel 4. Komposisi kimia abu batubara dari PLTU Ombilin

\begin{tabular}{clcc}
\hline \multirow{2}{*}{ No. } & \multirow{2}{*}{ Senyawa } & \multicolumn{2}{c}{ Komposisi, \% } \\
\cline { 3 - 4 } & & Abu Terbang & Abu Dasar \\
\hline 1 & $\mathrm{SiO}_{2}$ & 52,06 & 37,90 \\
2 & $\mathrm{Al}_{2} \mathrm{O}_{3}$ & 31,10 & 18,62 \\
3 & $\mathrm{Fe}_{2} \mathrm{O}_{3}$ & 4,26 & 5,02 \\
4 & $\mathrm{MnO}$ & 0,015 & 0,024 \\
5 & $\mathrm{MgO}$ & 0,75 & 0,64 \\
6 & $\mathrm{CaO}$ & 1,43 & 3,63 \\
7 & $\mathrm{Na} 2 \mathrm{O}$ & 0,15 & 0,17 \\
8 & $\mathrm{~K}_{2} \mathrm{O}$ & 4,21 & 2,38 \\
9 & $\mathrm{TiO}_{2}$ & 0,60 & 0,40 \\
10 & $\mathrm{P}_{2} \mathrm{O}_{5}$ & 0,092 & 0,078 \\
11 & $\mathrm{SO}_{3}$ & 0,37 & 1,15 \\
12 & $\mathrm{BaO}$ & 0,023 & 0,037 \\
\hline
\end{tabular}

\begin{tabular}{clcc}
\hline \multirow{2}{*}{ No. } & \multirow{2}{*}{ Senyawa } & \multicolumn{2}{c}{ Komposisi, \% } \\
\cline { 3 - 4 } & & Abu Terbang & Abu Dasar \\
\hline 13 & $\mathrm{Cr}_{2} \mathrm{O}_{3}$ & 0017 & 0,020 \\
14 & $\mathrm{CuO}$ & 0,011 & 0,007 \\
15 & $\mathrm{NiO}$ & 0,006 & 0,005 \\
16 & $\mathrm{Rb} 2 \mathrm{O}$ & 0,017 & 0,009 \\
17 & $\mathrm{SrO}$ & 0,010 & 0,010 \\
18 & $\mathrm{PbO}$ & 0,004 & 0,001 \\
19 & $\mathrm{Y}_{2} \mathrm{O}_{3}$ & 0,009 & 0,006 \\
20 & $\mathrm{ZnO}_{21}$ & 0,019 & 0,070 \\
21 & $\mathrm{ZrO}_{2}$ & 0,023 & 0,019 \\
22 & $\mathrm{LOI}$ & 4,85 & 29,82 \\
\hline
\end{tabular}

Senyawa yang dominan dalam abu terbang dan abu dasar (berurutan dari besar ke kecil) dengan kadar $>1 \%$ adalah $\mathrm{SiO}_{2}, \mathrm{Al}_{2} \mathrm{O}_{3}$. 
Tabel 5. Unsur LTJ pada abu batubara PLTU Ombilin

\begin{tabular}{llcc}
\hline \multirow{2}{*}{ No } & \multirow{2}{*}{ Unsur } & \multicolumn{2}{c}{ Komposisi, $p$ pm } \\
\cline { 2 - 4 } & & Abu terbang & Abu dasar \\
\hline 1 & Serium (Ce) & 71 & 32 \\
2 & Ittrium (Y) & 40 & 10 \\
3 & Lantanum (La) & 28 & 10 \\
4 & Neodimium (Nd) & 28 & 12 \\
5 & Samarium (Sm) & 2 & 0 \\
\hline
\end{tabular}

Tabel 5 menunjukkan unsur LTJ yang dominan adalah serium, Ittrium dan lantanum, sehingga dapat dikatakan bahwa mineral LTJ dalam abu batubara PLTU Ombilin merupakan monasit (Ce, La, Y, Th) fosfat. Kadar unsur LTJ pada abu terbang lebih tinggi dibandingkan dalam abu dasar. Pada intinya, beberapa unsur LTJ akan teruapkan pada temperatur tinggi saat pembakaran batubara, selanjutnya terkondensasi kembali setelah bergabung dengan partikel padatan pada abu terbang dan tertangkap pada Electrostatic
Precipitator (Perämäki, 2014). Mekanisme tersebut telah dipelajari di Jepang (Kashiwakura $d k k ., 2013)$. Hasil analisis XRD dan SEM-EDS pada abu terbang batubara Ombilin pada Gambar 4., menunjukkan hanya terdapat mineral kuarsa/quartz (silikon oksida), mulit (alumina silikat) dan magnetit (oksida besi). Abu terbang dari beberapa PLTU antara lain di Brasilia mempunyai komposisi mineral yang relatif sama, yaitu terdiri dari kuarsa dan mulit serta maghemit dan amorphous (termasuk sisa karbon dan aluminosilikat gelas) (Silva $d k k$., 2010). Analisis XRD dan SEM-EDS tersebut di atas belum dapat menunjukkan mineral pembawa logam tanah jarang, perlu analisis menggunakan SEM EDS (Scanning Electron Microscope Energy Dispersive Spectroscopy) per partikel seperti dilaksanakan oleh Zhang, Groppo dan Honaker (2015) pada penelitian abu batubara Hazard 4 Seam di United Kingdom sehingga monazit terdeteksi dengan jelas seperti pada Gambar 5.
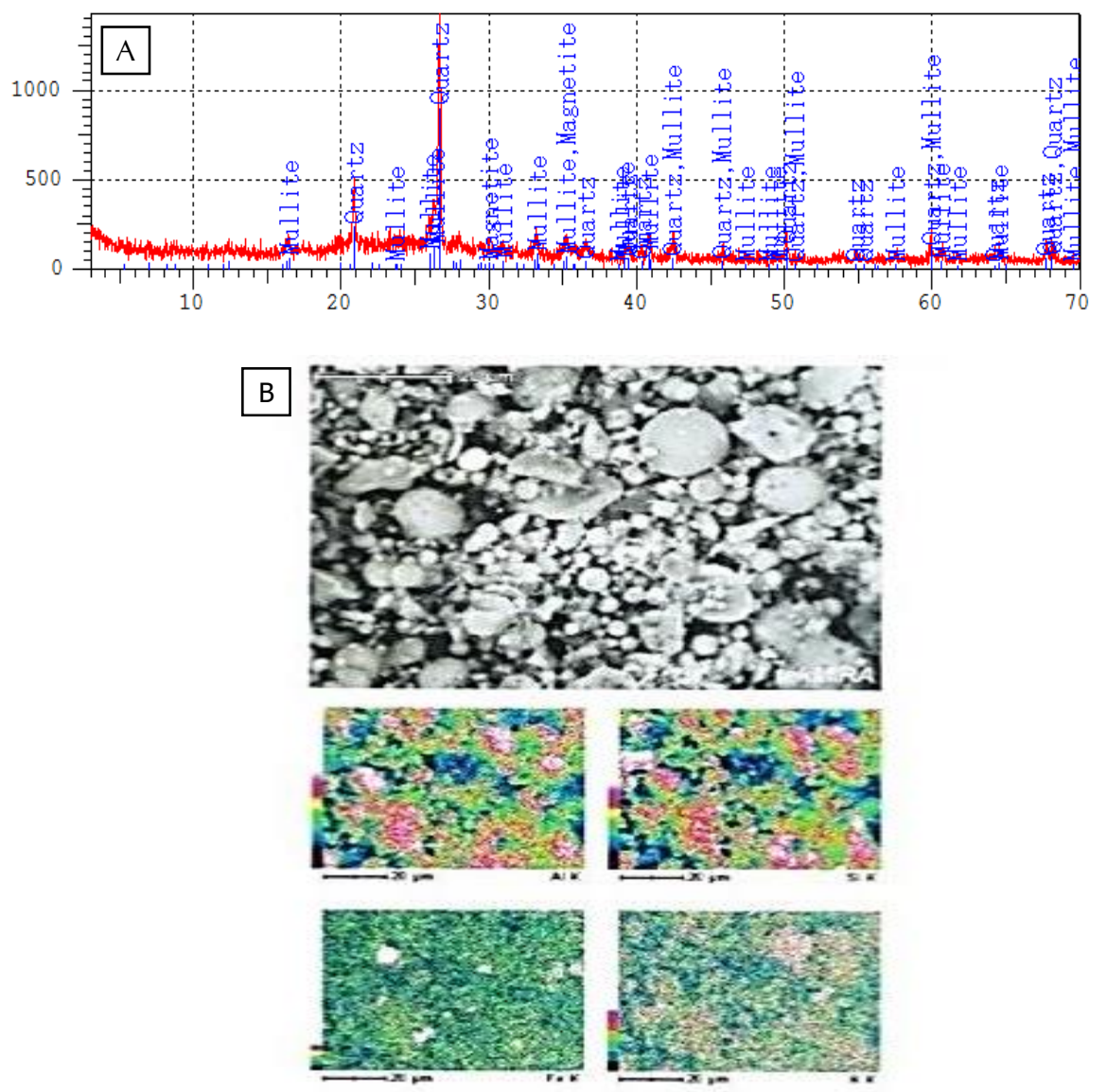

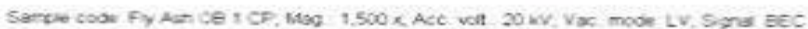

Gambar 4. Analisis XRD (a) dan SEM EDS (b) pada abu terbang PLTU Ombilin 

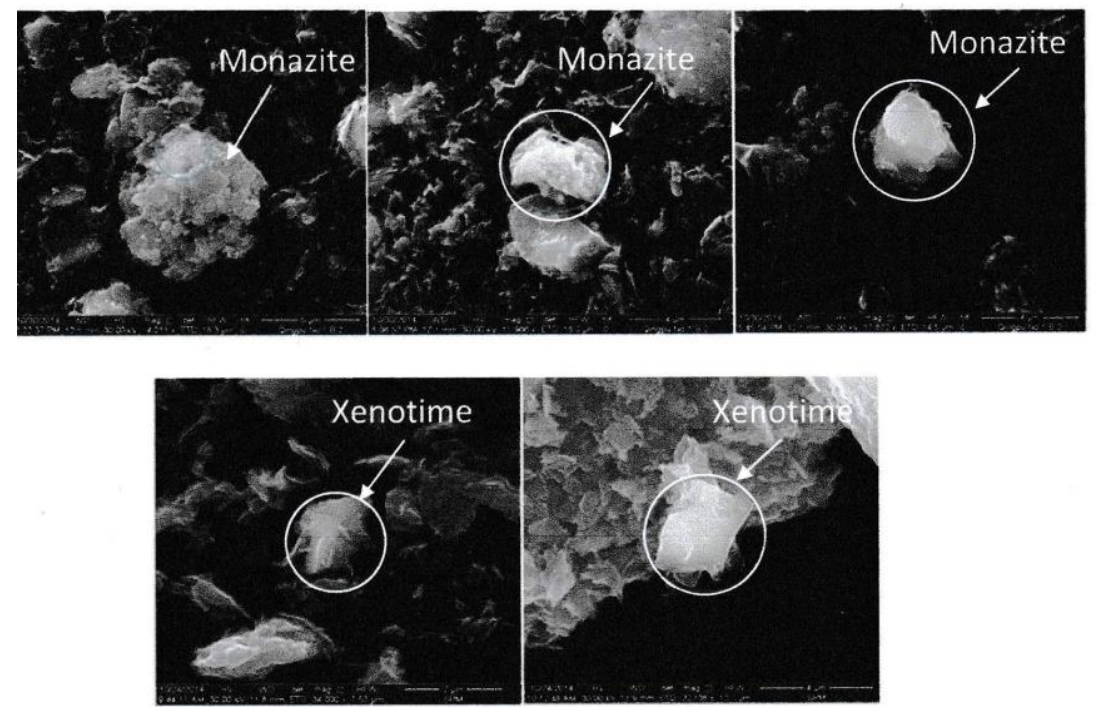

Sumber : Zhang, Groppo dan Honaker (2015)

Gambar 5. Mineral pembawa Logam Tanah Jarang pada batubara Hazard 4 Seam, United Kingdom

Kandungan LTJ pada abu batubara dari PLTU di Indonesia seperti yang ditunjukkan pada Tabel 5 masih relatif rendah dibandingkan dengan beberapa percontoh abu terbang dari beberapa PLTU di luar negeri seperti tercantum pada Tabel 3. Namun hasil penelitian batubara Indonesia yang digunakan di PLTU Hadong, Korea, dilaporkan mengandung unsur LTJ berupa $\mathrm{Nd}$ berjumlah 46,5 ppm dan Ce mencapai 103 ppm (Jegal, Thenepalli dan Ahn, 2015). Meskipun kandungan unsur LTJ pada abu batubara khususnya abu terbang pada PLTU di beberapa lokasi di Indonesia masih relatif kecil, akan tetapi potensi produksi abu terbang di Indonesia sudah cukup penting untuk dipertimbangkan sebagai nilai tambah lanjutan dari pemanfaatan energi batubara. Hal tersebut diperkuat dengan batubara Indonesia yang berkadar abu rendah sudah semakin langka. Beberapa wilayah di Kalimantan Selatan masih ditemukan cadangan batubara dengan kadar abu kurang dari $2 \%$, antara lain daerah penambangan PT Adaro Indonesia di Waringin (Suganal dan Supriatna, 2012). Umumnya batubara Indonesia bervariasi antara 2 - $10 \%$ dengan rata-rata sekitar 5 \% (Daulay, 2012).

Kadar LTJ dalam abu batubara yang layak untuk diolah minimal 500 ppm (Joshi $d k k$., 2013). Sesuai hasil karakterisasi LTJ dalam abu batubara yang sudah dilakukan dalam penelitian ini, menunjukkan bahwa kadar LTJ dalam abu batubara dari PLTU Ombilin kurang dari 100 ppm, sehingga belum termasuk layak untuk diekstraksi LTJ-nya. Namun, apabila abu batubara tersebut dilakukan pengolahan awal terlebih dahulu, dengan mengeliminasi senyawa yang dominan antara lain berupa silika dan alumina, maka kadar LTJ dalam abu batubara akan meningkat. Produk pengolahan awal tersebut kemungkinan akan layak untuk diekstrak menjadi unsur LTJ yang memenuhi spesifikasi standar.

\section{Peningkatan Kadar Unsur LTJ dalam Abu Batubara}

Sesuai hasil karakterisasi LTJ dalam abu batubara yang sudah dilakukan dalam penelitian ini, menunjukkan bahwa kadar LTJ dalam abu batubara dari PLTU Ombilin $<100$ ppm, sehingga belum ekonomis untuk diekstraksi LTJnya. Penelitian abu terbang batubara Indonesia yang digunakan pada PLTU Hadong, Korea, telah menunjukkan bahwa proses pengambilan unsur LTJ dari abu terbang tersebut belum dikategorikan ekonomis (Jegal, Thenepalli dan Ahn, 2015). Penulis tersebut mengutarakan bahwa terdapat beberapa cekungan batubara dengan unsur-unsur tanah jarang melebihi 1.000 ppm, antara lain Rettikhovka (Rusia) mencapai 1.141 ppm, Songzao (China) mencapai 2.446 ppm dan Aduunchuluun (Mongolia) dengan kandungan mencapai 5.178 ppm. 
Namun, apabila abu batubara PLTU Ombilin, terutama abu terbang, karena kadar unsur LTJ lebih besar (Tabel 5) dilakukan pengolahan terlebih dahulu dengan cara leaching (pelindian) terhadap senyawa yang dominan yaitu silika $>50 \%$ dan dipisahkan dari abu batubara, maka kadar LTJ dalam abu batubara akan meningkat sehingga kemungkinan akan layak untuk diekstrak.

Berdasarkan hasil karakterisasi dan analisis tersebut di atas, maka dilakukan penelitian benefisiasi atau peningkatan kadar secara fisika untuk menghilangkan pengotornya terutama silika dengan cara pemisahan berdasarkan perbedaan densitas agar terjadi peningkatan kadar LTJ dalam abu terbang batubara tersebut. Pemisahan gravitasi adalah metode yang efektif untuk mendapatkan mineral logam tanah jarang densitas tinggi (4$6 \mathrm{~g} / \mathrm{cm}^{3}$ ) dari mineral pengikut densitas rendah (Zhang $d k k$., 2015). Pemisahan dengan metode perbedaan densitas menunjukkan pengayaan LTJ tertinggi (Lin $d k k ., 2017)$.

Hasil benefisiasi terhadap abu terbang berupa konsentrat, middling dan ampas dilakukan analisis menggunakan SEM-EDS. Hasil analisis tersebut terlihat pada Tabel 6, Gambar 6, 7 dan 8.

Tabel 6. Hasil analisis SEM-EDS pada pemisahan berdasarkan densitas abu terbang PLTU Ombilin

\begin{tabular}{llcccc}
\hline \multirow{2}{*}{ No. } & \multirow{2}{*}{ Senyawa } & \multicolumn{4}{c}{ Konsentrasi (\%) } \\
\cline { 2 - 5 } & & Umpan & Konsentrat & Middling & Ampas \\
\hline 1 & $\mathrm{SiO}_{2}$ & 51,92 & 41,05 & 28,42 & 51,51 \\
2 & $\mathrm{Al}_{2} \mathrm{O}_{3}$ & 34,98 & 17,36 & 16,37 & 34,43 \\
3 & $\mathrm{FeO}$ & 7,46 & 23,53 & 28,61 & 8,48 \\
4 & $\mathrm{CaO}$ & 2,08 & 2,20 & 5,17 & 2,24 \\
5 & $\mathrm{TiO} 2$ & & - & 3,01 & - \\
6 & $\mathrm{~K} 2$ & 3,57 & 1,42 & - & - \\
7 & $\mathrm{PbO}$ & & 1,01 & - & - \\
8 & $\mathrm{ZrO}_{2}$ & & 13,43 & 13,95 & - \\
9 & $\mathrm{MoO}_{3}$ & & - & 4,48 & \\
\hline
\end{tabular}

JED-2200 Series
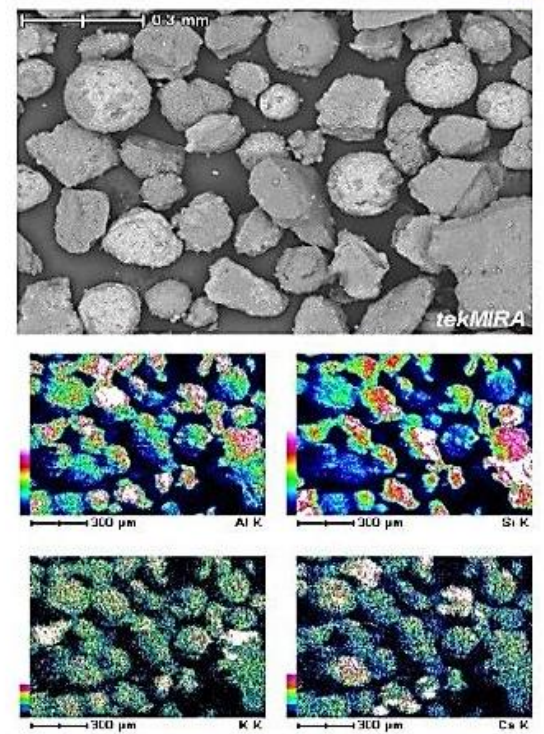

Gambar 6. Hasil analisis SEM-EDS pada konsentrat hasil pemisahan densitas untuk abu terbang
JEOL

JED-2200 Senes

JEDL
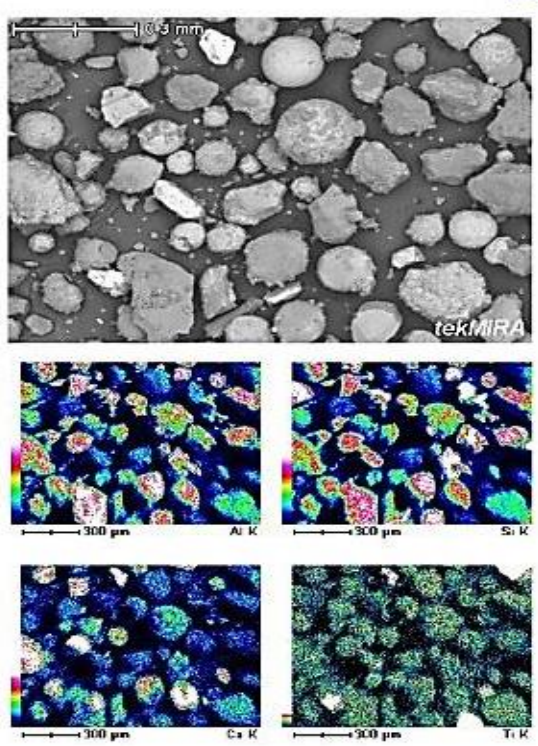

Gambar 7. Hasil analisis SEM-EDS pada middling hasil pemisahan densitas untuk abu terbang PLTU Ombilin 


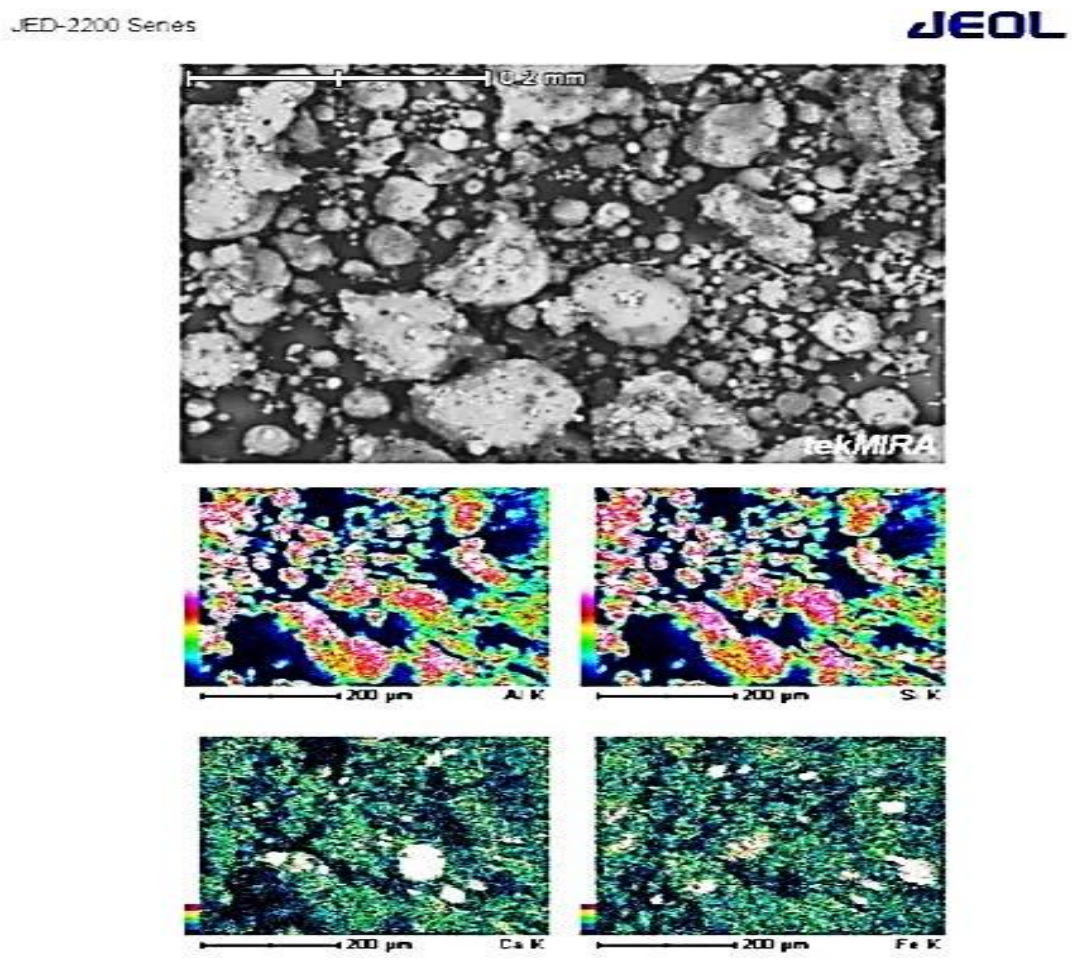

Gambar 8. Hasil analisis SEM-EDS pada ampas hasil pemisahan densitas untuk abu terbang PLTU Ombilin

Analisis SEM-EDS tersebut di atas setidaknya telah menunjukkan perubahan komposisi senyawa pada abu terbang. Dari hasil analisis pada Tabel 6, terlihat bahwa senyawa FeO terkonsentrasi pada konsentrat dan middling dengan peningkatan kadar mencapai sekitar 4 kali lipat, hal demikian karena senyawa $\mathrm{FeO}$ mempunyai densitas tertinggi, yaitu $5,7 \mathrm{~g} / \mathrm{cm}^{3}$ dibanding senyawa lainnya pada material hasil benefisiasi. Senyawa $\mathrm{Al}_{2} \mathrm{O}_{3}$ relatif merata pada konsentrat dan middling hasil benefisiasi.

Sesuai dengan perilaku pemisahan berdasarkan perbedaan densitas maka komposisi pada ampas didominasi oleh senyawa $\mathrm{SiO}_{2}$ dan $\mathrm{Al}_{2} \mathrm{O}_{3}$ karena kedua senyawa tersebut mempunyai densitas paling rendah yaitu 2,65 dan 3,69 g/ $\mathrm{cm}^{3}$ relatif tidak mengalami perubahan kompisisi. Komposisi senyawa kimia pada middling menunjukkan bahwa silika telah berkurang cukup banyak dari 51,92 menjadi 28,49 \% demikian pula alumina $\left(\mathrm{Al}_{2} \mathrm{O}_{3}\right)$ dari 34,95 menjadi $16,37 \%$. Sedangkan $\mathrm{FeO}$ meningkat tajam sampai $28,61 \%$ yang berarti meningkat empat kali lipat konsentrasinya. Secara umum densitas unsur-unsur LTJ relatif tinggi yaitu $4-8,16$ $\mathrm{g} / \mathrm{cm}^{3}$ sehingga unsur LTJ cenderung akan terkonsentrasi pada konsentrat, sedangkan silika dan alumina akan lebih banyak terkonsentrasi dalam ampas (British Geological Survey, 2011; Honaker dkk., 2016).

Analisis unsur LTJ pada hasil benefisiasi pada Tabel 6 belum terdeteksi adanya unsur logam tanah jarang. Oleh karena itu percontoh dari middling dan ampas dilakukan analisis menggunakan ICP yang hasilnya ditunjukkan pada Tabel 7 dan Gambar 9.

Tabel 7. Perbandingan kandungan Unsur LTJ setelah proses benefisiasi

\begin{tabular}{|c|c|c|c|c|}
\hline \multirow[t]{2}{*}{ No } & \multirow[t]{2}{*}{ Unsur } & \multicolumn{3}{|c|}{ Kandungan, ppm } \\
\hline & & $\begin{array}{l}\text { Abu } \\
\text { terbang }\end{array}$ & Middling & Ampas \\
\hline 1 & Cerium/Ce & 71 & 6,6883 & 5,0219 \\
\hline 2 & Ittrium/Y & 40 & 6,1888 & 3,9429 \\
\hline 3 & Lantanum/La & 28 & 5,4296 & 3,9777 \\
\hline 4 & Neodimium/Nd & 28 & 3,7861 & 1,7403 \\
\hline 5 & Samarium/Sm & 2 & 9,3267 & 3,9429 \\
\hline
\end{tabular}




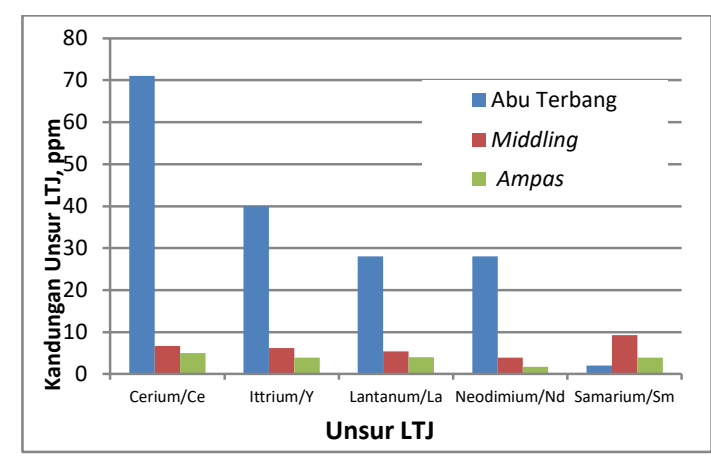

Gambar 9. Perbandingan kandungan unsur LTJ setelah proses benefisiasi

Data pada Tabel 7 dan Gambar 9, terlihat peningkatan kandungan unsur LTJ hanya terjadi pada unsur Sm. Kandungan unsurunsur $\mathrm{Ce}, \mathrm{Y}$, La dan $\mathrm{Nd}$ menurun cukup tajam diyakini berpindah pada aliran konsentrat. Indikasi tersebut terlihat dari mineral pembawa LTJ yang berupa monasit mengandung unsur $\mathrm{Ce}$, La dan $\mathrm{Y}$ seperti diuraikan pada sub bagian karakterisasi abu batubara dari PLTU Ombilin, di samping densitas unsur-unsur $\mathrm{Ce}, \mathrm{Y}, \mathrm{La}, \mathrm{Nd}$ dan $\mathrm{Sm}$ cukup tinggi dibanding densitas mineral lainnya, yaitu masing masing 8,$16 ; 4,4 ; 6,0 ; 7$ dan $7,5 \mathrm{~g} / \mathrm{cm}^{3}$. Pada sisi lain, unsur Sm tidak tergabung langsung dengan mineral monasit sehingga tidak terbawa aliran konsentrat. Kandungan unsur $\mathrm{Sm}$ pada abu terbang meningkat dari 2 ppm menjadi 9,3267 ppm pada middling benefisiasi, dan pada ampas meningkat dari 2 ppm menjadi 3,9429 ppm.

Ditinjau dari kuantitas kandungan unsur Sm pada middling yaitu 9,3 ppm terlihat cukup berarti, meskipun masih dalam orde ppm, namun hampir sama dengan kandungan terkecil unsur LTJ dalam banyak formasi batuan, yaitu pada kisaran 10 - 300 ppm (Atmawinata dkk., 2014).

Kegunaan unsur Sm umumnya untuk pembuatan magnet (Humphries, 2013). Jenis magnet yang telah diproduksi adalah dari bahan SmCo (magnet kobalt samarium). Keutamaan magnet SmCo adalah mampu mempertahankan kekuatan magnet pada suhu tinggi. Teknologi magnet sangat dibutuhkan pada pembangkit listrik tenaga angin. Hal ini sangat berpotensi mendukung realisasi perluasan pemanfaatan energi baru terbarukan dan dapat menggeser peranan energi fosil.
Tingginya kadar $\mathrm{FeO}$ dan rendahnya $\mathrm{Al}_{2} \mathrm{O}_{3}$ dan $\mathrm{SiO}_{2}$ akan sangat memudahkan pemisahan lanjutan menggunakan magnetic separator dan diikuti peningkatan kadar unsur LTJ melalui leaching dengan asam nitrat yang dicampur dengan tributil fosfat dan kerosin pada suhu $90^{\circ} \mathrm{C}$ yang merupakan patent no. 0287653a1 di USA dan terakhir pemisahan menggunakan pertukaran ion (Sahoo $d k k$., 2016).

Berdasarkan hasil analisis pada Tabel 6, maka upaya peningkatan kadar unsur LTJ dalam abu terbang batubara PLTU Ombilin dapat diskemakan sebagai berikut :

a. pemisahan berdasarkan densitas menggunakan meja goyang,

b. material output meja goyang berupa middling dilakukan pemisahan menggunakan magnetic separator, untuk memaksimalkan efisiensi leaching dalam larutan asam bercampur tributil fosfat dan kerosin,

c. pertukaran ion.

Untuk mengoptimalkan pemanfaatan abu batubara dari PLTU dan mendapatkan senyawa kimia yang berharga tinggi maka abu batubara tersebut seyogyanya tidak dipandang sebagai suatu limbah proses pembakaran batubara namun seharusnya disetarakan sebagai bahan baku atau sumber senyawa LTJ. Dengan demikian pemanfaatan abu batubara terutama abu terbang terlebih dahulu dilakukan ekstraksi unsur-unsur LTJ, selanjutnya abu terbang bebas LTJ tersebut dapat dimanfaatkan sebagai bahan bangunan maupun kegiatan lain seperti yang telah umum digunakan.

\section{KESIMPULAN}

Abu batubara dari PLTU Ombilin berupa abu terbang dan abu dasar menunjukkan adanya kandungan unsur-unsur LTJ berupa Cerium, Neodimium, Lantanum, Ittrium dan Samarium meskipun kadar unsur tersebut relatif rendah, kurang dari 100 ppm. Kandungan unsur LTJ dalam abu terbang lebih tinggi dibandingkan pada abu dasar sehingga upaya peningkatan kadar lebih ekonomis dilakukan terhadap abu terbang juga karena produksi abu terbang mencapai lebih dari $70 \%$ dari total abu batubara yang dihasilkan. Hasil benefisiasi 
pada abu terbang telah meningkatkan kandungan unsur Sm pada middling dari 2 ppm menjadi 9,3267 ppm dan pada ampas dari 2 ppm menjadi 3,9429 ppm. Fakta kandungan unsur-unsur LTJ pada abu terbang dapat dipandang sebagai sumber bahan baku dari unsur-unsur logam tanah jarang yang terkandung dalam abu batubara, terutama sebagai sumber bahan magnet permanen mendukung era energi non konvensional.

\section{UCAPAN TERIMAKASIH}

Penulis mengucapkan terima kasih yang sebesar-besarnya kepada PLTU Ombilin atas kerja sama dalam penyediaan percontoh abu batubara yang digunakan untuk penelitian di Laboratorium Batubara dan Laboratorium Mineral, Pusat Penelitian dan Pengembangan Teknologi Mineral dan Batubara, Bandung.

\section{DAFTAR PUSTAKA}

Ahn, J. W., Thriveni, T. and Jegal, Y. (2015) "Occurrence and distribution of rare earths with different coal power plants ash and recovery of critical rare earths from coal ash for simultaneous utilization of CO2, 2015," in 2015 World of Coal Ash Conference in Nasvhille, pp. 1-14.

Atmawinata, A., Yahya, F., Widhianto, S., Roosmariharso, Irianto, D., Adlir, A., Susilo, Y., Radjid, W., Massaruddin, Noviansyah, D., Sutjiatmo, A. I., Shinta V., Wuri, S., Sutjiatmo, B. P. and Ardhana (2014) Telaahan penguatan struktur industri pemetaan potensi logam tanah jarang di Indonesia. Kementerian Perindustrian Republik Indonesia. Available at http://www.kemenperin.go.id/download/8164 /Telaahan-Penguatan-Struktur-Industri-2014PEMETAAN-POTENSI-LOGAM-TANAHJARANG-DI-INDONESIA.

Binnemans, K., Jones, P. T., Blanpain, B., Van Gerven, T. and Pontikes, Y. (2015) "Towards zero-waste valorisation of rare-earthcontaining industrial process residues: a critical review," Journal of Cleaner Production, 99, pp. 17-38. doi: 10.1016/j.jclepro.2015.02.089.

British Geological Survey (2011) "Rare earth elements." British Geological Survey, pp. 153. Available https://www.bgs.ac.uk/downloads/start.cfm?id $=1638$.

Daulay, B. (2012) "Perkembangan industri batubara Indonesia," in Daulay, B., Umar, D. F., Suprapto, S., Ningrum, N. S., and Huda, M. (eds.) Teknologi Pemanfaatan Batubara Indonesia. Bandung: Puslitbang tekMIRA, pp. 13-31.

Franus, W., Wiatros-Motyka, M. M. and Wdowin, M. (2015) "Coal fly ash as a resource for rare earth elements," Environmental Science and Pollution Research, 22(12), pp. 9464-9474. doi: 10.1007/s11356-015-4111-9.

Haryadi, G. D. (2006) "Pengaruh penambahan fly ash melalui proses separasi iron oxide dan coal terhadap keausan aluminium," Rotasi, 8(4), pp. 18-26. doi: 10.14710/rotasi.8.4.1826.

Honaker, R., Groppo, J., Bhagavatula, A., Rezaee, M. and Zhang, W. (2016) "Recovery of rare earth minerals and elements from coal and coal by product," in Coal Prep 2016 - Annual Coal Processing Exhibition \& Conference. Louisville, Kentucky. Available at: https://www.researchgate.net/publication/305 001377 Recovery of Rare Earth Minerals a nd_Elements_from_Coal_and_Coal_Byproduc ts.

Hower, J., Thomas, G. and Hopps, S. (2014) "Trends in coal utilization and coal combustion product production in Kentucky: Results of the 2012 survey of power plants," Coal Combustion and Gasification Products, 6(1), pp. 35-41. doi: 10.4177/CCGP-D-1400006.1.

Humphries, M. (2013) Rare earth elements the global supply chain. Available at: https://fas.org/sgp/crs/natsec/R41347.pdf.

International Energy Agency (2012) Trace element emissions from coal. No .12/13. Available at: https://www.iea-coal.org/wpcontent/uploads/dlm uploads/reports/emmisi onscontrol/Trace-element-emissions-CCC34.pdf.

Jegal, Y., Thenepalli, T. and Ahn, J. (2015) "The crucial role of coal for coal-fired power plants affected by the geological origin: South Korea," International Journal of Emerging Technology and Advanced Engineering, 5(3), pp. 391-398. Available at: http://www.ijetae.com/files/Volume5Issue3/lJ ETAE_0315_73.pdf. 
Joshi, P. B. (2013) "A low cost rare earth elements recovery technology." Andover: Physical Sciences Inc., pp. 1-17. Available at: http://www.psicorp.com/pdf/library/VG13060.pdf.

Joshi, P. B., Preda, D. V., Skyler, D. A., Tsinberg, A., Green, B. D. and Marinelli, W. J. (2013) "Recovery of rare earth elements and compounds from coal." United State. Available at: https://patents.google.com/patent/US2013028 7653A1/en.

Juda-Rezler, K. and Kowalczyk, D. (2013) "Size distribution and trace elements contents of coal fly ash from pulverized boilers," Journal of Environmental Studies, 22(1), pp. 25-40. Available at: https://www.pjoes.com/abstracts/2013/Vol22/ No01/02.html.

Kashiwakura, S., Kumagai, Y., Kubo, H. and Wagatsuma, K. (2013) "Dissolution of rare earth elements from coal fly ash particles in a dilute H2SO4 solvent," Open Journal of Physical Chemistry, 03(02), pp. 69-75. doi: 10.4236/ojpc.2013.32009.

Kusuma, G. J., Shimada, H., Sasaoka, T., Matsui, K., Nugraha, C., S. Gautama, R. and Sulistianto, B. (2012) "An evaluation on the physical and chemical composition of coal combustion ash and its co-placement with coal-mine waste rock," Journal of Environmental Protection, 03(07), pp. 589596. doi: 10.4236/jep.2012.37071.

Lin, R., Howard, B. H., Roth, E. A., Bank, T. L., Granite, E. J. and Soong, Y. (2017) "Enrichment of rare earth elements from coal and coal by-products by physical separations," Fuel, 200, pp. 506-520. doi: 10.1016/j.fuel.2017.03.096.

Mayfield, D. B. and Lewis, A. S. (2013) "Environmental review of coal ash as a resource for rare earth and strategic elements," in 2013 World of Coal Ash (WOCA) Conference, p. 10. Available at: http://www.flyash.info/2013/051-Mayfield2013.pdf.

Perämäki, S. (2014) Method development for determination and recovery of rare earth elements from industrial fly ash. University of Jyväskylä. Available at: https://jyx.jyu.fi/dspace/handle/123456789/45 043.

Sahoo, P. K., Kim, K., Powell, M. A. and Equeenuddin, S. M. (2016) "Recovery of metals and other beneficial products from coal fly ash: A sustainable approach for fly ash management," International Journal of Coal Science \& Technology, 3(3), pp. 267283. doi: 10.1007/s40789-016-0141-2.

Silva, L., Ward, C., Hower, J., Izquierdo, M., Waanders, F., Oliveira, M., Li, Z., Hatch, R. and Querol, X. (2010) "Mineralogy and leaching characteristics of coal ash from a major Brazilian power plant," Coal Combustion and Gasification Products, 2(1), pp. 51-65. doi: 10.4177/CCGP-D-1000005.1 .

Smith, R. D., Campbell, J. A. and Nielson, K. K. (2006) Mechanisms for trace element enrichment in fly ash during coal combustion. Washington. Available at: https://web.anl.gov/PCS/acsfuel/preprint archive/Files/23_1_ANAHEIM_0378 0196.pdf.

Suganal and Supriatna, W. (2012) "Pembuatan kokas," in Daulay, B., Umar, D. F., Suprapto, S., Ningrum, N. S., and Huda, M. (eds.) Teknologi Pemanfaatan Batubara Indonesia. Bandung: Puslitbang tekMIRA, pp. 199-216.

Terzić, A., Pavlović, L. and Miličić, L. (2013) "Evaluation of lignite fly ash for utilization as component in construction materials," International Journal of Coal Preparation and Utilization, 33(4), pp. 159-180. doi: 10.1080/19392699.2013.776960.

Thriveni, T., Jegal, Y. and Ahn, J. W. (2015) "Characteristic studies yttrium extracted from coal ash South Korea," in Mastorakis, N. E., Rudas, I., Shitikova, M. V., and Shmaliy, Y. S. (eds.) Proceedings of the International Conference on Energy, Environment, Ecosystems, and Development (EEED 2015). Barcelona: Energy, Environment, Ecosystems, and Development, pp. 20-25. Available at: http://www.inase.org/library/2015/barcelona/ bypaper/EEED/EEED-03.pdf.

Tolhurst, L. (2015) "Commercial recovery of metals from coal ash," in 2015 World of Coal Ash (WOCA) Conference. Nasvhille: World of Coal Ash (WOCA), pp. 1-9. Available at: http://www.flyash.info/2015/185-tolhurst2015.pdf.

Vulcan, T. (2014) Cracking the rare earth code in coal combustion products, ETF.com. Available at: http://www.etf.com/sections/features-andnews/5591-cracking-the-rare-earth-code-incoal-combustion-products?nopaging $=1$ (Accessed: April 28, 2016). 
Wardhani, E., Sutisna, M. and Dewi, A. H. (2012) "Evaluasi pemanfaatan abu terbang (fly ash) batubara sebagai campuran media tanam pada tanaman tomat," Jurnal Itenas Rekayasa, 16(1), pp. 44-56. Available at: https://ejurnal.itenas.ac.id/index.php/rekayasa /article/view/438.

Zepf, V., Simmons, J., Reller, A., Ashfield, M. and Rennie, C. (2014) Materials critical to the energy industry: An introduction. 2nd Ed. London: BP. Available at: https://www.bp.com/content/dam/bp/pdf/sust ainability/group-

reports/ESC_Materials_handbook_BP_Apr201 4.pdf.
Zhang, W., Groppo, J. and Honaker, R. (2015) "Ash beneficiation for REE recovery," in 2015 World of Coal Ash (WOCA) Conference. Nasvhille: World of Coal Ash (WOCA), pp. 1-11. Available at: http://www.flyash.info/2015/194-Groppo2015.pdf.

Zhang, W., Rezaee, M., Bhagavatula, A., Li, Y., Groppo, J. and Honaker, R. (2015) "A review of the occurrence and promising recovery methods of rare earth elements from coal and coal by-products," International Journal of Coal Preparation and Utilization, 35(6), pp. 295-330.

doi: 
